ISSN 1392-3196 / e-ISSN 2335-8947

Zemdirbyste-Agriculture, vol. 106, No. 2 (2019), p. 123-128

DOI 10.13080/z-a.2019.106.016

\title{
Fruit quality of cherry and large fruited tomato genotypes as influenced by water deficit
}

\author{
Ivana PETROVIĆ ${ }^{1}$, Sladjana SAVIĆ ${ }^{2}$, Zorica JOVANOVIĆ ${ }^{1}$, Radmila STIKIĆ ${ }^{1}$, \\ Beatrice BRUNEL ${ }^{3}$, Sylvie SÉRINO ${ }^{3}$, Nadia BERTIN ${ }^{3}$ \\ ${ }^{1}$ University of Belgrade \\ 11080 Belgrade, Serbia \\ E-mail: ivana.petrovic@agrif.bg.ac.rs \\ ${ }^{2}$ The John Naisbitt University \\ 11070 Belgrade, Serbia \\ ${ }^{3}$ French National Institute for Agricultural Research (INRA) \\ UR 1115, Domaine Saint Paul, CS 4050984914 Avignon Cedex 9, France
}

\begin{abstract}
The aim of the present study was to investigate the effect of long term moderate drought stress on fruit yield and quality of four parents of the MAGIC TOM population and to gain insight into the differences in sensitivity to drought between large fruited and cherry tomatoes. Results showed that long term water deficit had a negative effect on fresh mass and fruit diameter that were more expressed in cherry tomatoes than in large fruited ones. Long term moderate water deficit can improve fruit taste in large fruited tomato genotypes by active metabolic accumulation of soluble sugar and organic acid (sucrose and citric acid), which are also osmotic active compounds. The reduction in fruit growth of cherry tomatoes compared to large fruits could be compensated for by improving fruit nutritional value (ascorbic acid, carotenoids and antioxidant activity) through both concentration and metabolic responses.
\end{abstract}

Keywords: antioxidant compounds, drought, MAGIC TOM, nutritional value, Solanum lycopersicum.

\section{Introduction}

Drought limits productivity of crops and vegetables by inducing different morphological, physiological and molecular changes in plants, which consequently reduces the yield and its quality (Ashraf, Harris, 2013). Adaptation measures to mitigate the reduction of yield induced by climate change besides the application of different irrigation strategies (including partial root drying) also include the use of drought resistant genotypes to increase crop water productivity (Jovanovic, Stikic, 2012; Sun et al., 2014). However, the prerequisite for the development of resistant genotypes is a better understanding of the plant response and adaptation to drought stress, the improvement of phenotyping, the selection of key-genes involved in the resistance to drought and the evaluation of the impact of resistance on crop yield and quality. These are very difficult tasks, because reactions of plants to drought are the complex phenomenon, where the plant response depends on the species or genotypes, the type, duration or intensity of drought and on phenological stage, in which drought stress is experienced (Chaves et al., 2003).

Tomato taste and flavour rely on the balance among essential compounds such as sugars, organic acids,

secondary metabolites (carotenoids and polyphenols) and ascorbic acid. Crop production and fruit quality are often exposed to several stress factors and their interaction affects plants to a larger intensity than the effect of one individual stress (Lipiec et al., 2013). However, the effects of water deficit on fruit yield and quality mostly depended on the genotype, on the plant and fruit developmental stage at the time stress occurs and on the interactions with other stress factors (Ripoll et al., 2014).

Generally, water deficit is expected to reduce the flux of water to fruit, to stimulate the accumulation of osmotic compounds like soluble sugars and acids and to trigger the synthesis of antioxidant compounds, including vitamin $\mathrm{C}$ and carotenoids (Dorais et al., 2008; Fanciullino et al., 2014). However, this increase may result either from concentration effects due to a decrease in the amount of water accumulated in the fruit and/or from a higher synthesis of specific metabolites. Accordingly, Zheng et al. (2013) and Ripoll et al. (2014) demonstrated that water deficit could also have beneficial effects on tomato fruit quality and health value with minimal reduction of the yield.

Please use the following format when citing the article:

Petrović I., Savić S., Jovanović Z., Stikić R., Brunel B., Sérino S., Bertin N. 2019. Fruit quality of cherry and large fruited tomato genotypes as influenced by water deficit. Zemdirbyste-Agriculture, 106 (2): 123-128. DOI 10.13080/z-a.2019.106.016 
Currently, the main challenge is to develop plants not only able to survive stress, but also able to grow under adverse conditions with reasonable biomass production, overcoming the negative correlation between drought resistant traits and productivity, which was often present in previous breeding programs (Chaves, Oliveira, 2004; Causse et al., 2011). For tomato, the MAGIC TOM (the multi-parent advanced generation intercross) population encompasses the highest rate of allelic variability in tomato (Ranc, 2010) and offers a potential source of genetic variation to outline traits useful for stress breeding programs for both cherry tomatoes and tomatoes with long fruits.

The aim of the present study was to investigate the effect of long term moderate drought stress on fruit yield and quality of four parents of the MAGIC TOM population and to gain insight into the differences in sensitivity to drought between large fruited tomato and cherry tomatoes.

\section{Materials and methods}

Plant material and experimental conditions. The study was performed on four tomato (Solanum lycopersicum L.) genotypes from the eight parents of the MAGIC TOM (the multi-parent advanced generation inter-cross) population, which offers the largest allelic variability observed in tomato (Ranc, 2010). The genotypes selected were two cherry or cocktail tomatoes ('Plovdiv' and LA1420) and two tomatoes ('Levovil' and LA0147) with large fruits. The experiment was conducted in the glasshouse in 2014 (March-July) at INRA, Avignon, France.

The plants were raised from the seeds and transplanted into $4 \mathrm{~L}$ pots filled with compost mixture: $60 \%$ black peat, $30 \%$ fibrous peat and $10 \%$ white peat, with $\mathrm{pH}=6$ and with clay. Over the whole experimental period, the mean daily photosynthetically active radiation (PAR) was from 5 to $11 \mathrm{~mol} \mathrm{~m}^{-2}$ day $^{-1}$, the air temperature and relative humidity remained relatively stable (the average temperature $24-28 / 17-21^{\circ} \mathrm{C}$ day/night and the air humidity $51-56 / 69-73 \%$ day/night).

Water deficit treatment. At the stage of $2^{\text {nd }}$ flower truss anthesis, water deficit was implemented and soil humidity was maintained around $25 \%$ of maximum water retention capacity until fruit harvesting (red-ripe stage). Control plants were irrigated until the end of experiment in order to maintain optimal soil humidity $(70 \%$ of maximum water retention capacity of the compost). Soil humidity was maintained by an automated irrigation system and controlled by a Wireless Control Module sensor ("Grodan", The Netherlands).

Measurements of fruit quality parameters. Fruits were harvested at full maturity, red-ripe stage. Soluble sugars (glucose, fructose and sucrose) and organic (citric and malic) acids were extracted following the protocol by Gomez et al. (2002). The high-pressure liquid chromatography (HPLC) analyses were done by HPLC system ("Waters", USA) with a UV detector at $210 \mathrm{~nm}$. The separation of sugars was carried out on a Sugar-Pac I column $(300 \times 6.5 \mathrm{~mm})$ ("Waters", ref. WAT088141) equipped with a pre-column ("Waters", ref. WAT015209). The mobile phase consisted of $\mathrm{Na}_{2} \mathrm{Ca}$ EDTA (50 mg L-1) and was delivered at a flow rate of $0.6 \mathrm{~mL} \mathrm{~min}{ }^{-1}$. The separation of organic acids was carried out on a Shodex RS pak KC-811 column $(300 \times 8 \mathrm{~mm})$ equipped with a pre-column Shodex RS pak KC-G $(50 \times$ $6 \mathrm{~mm}$ ). The mobile phase consisted of $0.1 \% \mathrm{H}_{3} \mathrm{PO}_{4}$ (flow rate $1 \mathrm{~mL} \mathrm{~min}^{-1}$ ).

Carotenoids (phytoene, lycopene, $\beta$-carotene and lutein) were extracted by micro-method and analysed by HPLC (Serino et al., 2009). Carotenoid analyses were performed with a HPLC system with a diode array detector ("Agilent", USA). The separation was carried out on two columns (VWR Merck, ref. 1.02129.0001, Chromolith ${ }^{\circledR}$ RP-18 endcapped $100 \times 4.6 \mathrm{~mm}$ monolithic) with a precolumn (VWR Merck, ref. 1.51452.0001, Chromolith ${ }^{\circledR}$ RP-18 endcapped $10 \times 4.6 \mathrm{~mm}$ monolithic). Mobile phase consisted of acetonitrile, ethyl-acetate and ultrapure water in the range of 53:40:7 with a flow rate of $1 \mathrm{~mL} \mathrm{~min}^{-1}$. For peak identification and calculation of analysed carotenoids, the HPLC standards (Cayman Chemical, USA) were used.

The ascorbic acid analysis included two assays: total ascorbic acid (with the addition of dithiothreitol - DTT) and reduced ascorbic acid (without of DTT) content according to the protocol by the Stevens et al. (2006). Grounded fruits were homogenized with cold 6\% trichloroacetic acid (TCA), vortexed (20 s), centrifuged (15 minutes, $4^{\circ} \mathrm{C}, 13200 \times \mathrm{rpm}$ ), and then the supernatant was used for further analysis. After addition of DTT (total ascorbic assay) and phosphate buffer (reduced ascorbic assay) the microplate was incubated at $37^{\circ} \mathrm{C}$ for 20 minutes. In the wells with DTT the N-ethylmalemide $\left(\mathrm{C}_{6} \mathrm{H}_{7} \mathrm{NO}_{2}\right)$ was added. The plate was incubated with a colouring agent for 60 minutes at $37^{\circ} \mathrm{C}$. The absorbance was read at $550 \mathrm{~nm}$ using a microplate reader ("Tecan", Switzerland) and the results were expressed on fruit fresh weight basis.

The antioxidant capacity of the samples was measured using 2,2'-azino-bis(3-ethylbenzothiazoline6-sulphonic acid (ABTS assay), following the modified protocol of Miller et al. (1993). Extraction of ground tomato fruit samples was done by $80 \%$ ethanol, and then the samples were vortexed, centrifuged $(9000 \times \mathrm{rpm})$ and finally the supernatant was used for analysis. ABTS ${ }^{++}$ radical cation was prepared by dissolving ABTS in phosphate-buffered saline (PBS) buffer $(\mathrm{pH}=7.4)$ and adding manganese dioxide to oxidize ABTS. The absorbance for standard curve and samples was measured at $734 \mathrm{~nm}$ with a Spectro UV-VIS RS 1166 (Labomed Inc., USA). The results were expressed as $\mu$ mol of Trolox equivalent antioxidant capacity (TEAC) $\mathrm{kg}^{-1}$ fresh weight (FW).

Statistical analysis was performed using software SigmaPlot, version 11.0 (Systat Software Inc., USA). Descriptive statistic was done for each group of measurement. Standard errors of the means were calculated and they are stated in the tables. Differences between treatments were estimated by a two-way ANOVA/MANOVA procedure Statistica 99 (StatSoft Inc., USA), and the Student's $t$-test was used to determine the significant differences between the means.

\section{Results and discussion}

Exposure of the plants to long term moderate drought stress had a reducing effect on fruit fresh mass in all investigated genotypes (Table 1), but the effects were more expressed in cherry tomatoes ('Plovdiv' and LA1420) than in large fruits tomatoes ('Levovil' and LA0147). 
Table 1. Fruit fresh mass, dry matter content and diameter of tomato fruits exposed to optimal and water deficit conditions

\begin{tabular}{ccccccc}
\hline \multirow{2}{*}{ Genotype } & \multicolumn{2}{c}{ Fresh mass g } & \multicolumn{2}{c}{ Dry matter $\%$} & \multicolumn{2}{c}{ Diameter mm } \\
\cline { 2 - 7 } & control & drought & control & drought & control & drought \\
\hline Plovdiv & $45.20 \pm 1.95$ & $19.33 \pm 0.70^{* * *}$ & $7.52 \pm 0.13$ & $9.59 \pm 0.14^{* * *}$ & $41.87 \pm 0.76$ & $31.41 \pm 0.54^{* * *}$ \\
Levovil & $104.05 \pm 9.08$ & $88.29 \pm 9.36 \mathrm{~ns}$ & $5.26 \pm 0.32$ & $6,49 \pm 0.38^{* * *}$ & $65.57 \pm 4.33$ & $57.05 \pm 2.28 \mathrm{~ns}$ \\
LA1420 & $64.04 \pm 7.11$ & $25.31 \pm 5.14^{* * *}$ & $6.61 \pm 0.10$ & $8,83 \pm 0.44^{* * *}$ & $53.83 \pm 2.14$ & $38.66 \pm 3.36^{* *}$ \\
LA0147 & $107.84 \pm 12.71$ & $57.30 \pm 6.26^{* * *}$ & $5.94 \pm 0.18$ & $7,69 \pm 0.47^{* * *}$ & $60.79 \pm 3.16$ & $52.37 \pm 3.03 \mathrm{~ns}$ \\
\hline
\end{tabular}

Note. Values are mean \pm standard error $(\mathrm{n}=6)$; levels of significance are represented by $* P<0.05, * * P<0.01$ and $* * * P \leq 0.001$, ns - not significant.

In all genotypes the dry matter content of fruit increased, while reduction of fruit diameter was statistically significant only for the cherry tomatoes. The effects of drought could be different depending on the intensity of the stress and the stage of fruit development when a water deficit is applied (Kuşçu et al., 2014; Chen et al., 2015). This could explain the discrepancy of our and Ripoll et al. (2016 b) results, where reduction in fruit fresh weight of cherry genotypes was not found after short term repeated drought and recovery periods at specific developmental stages. Our experiment started at anthesis, prolonged until maturity stage, and our plants were exposed to a much longer period of water deficit.
Soluble sugars and organic acids are major osmotic compounds that accumulate in fleshy tomato fruits and determine its taste. Our results revealed specific genotypic differences between cherry and large fruits. The results showed that in all genotypes glucose and fructose content had a tendency to decrease, although the sucrose concentration, as the most important trait for sweetness perception and marketing value of the fruits (Baldwin et al., 2008), increased in all genotypes, especially in large fruited tomatoes (Table 2).

On the contrary, results of Ripoll et al. (2016 a) demonstrated that the majority of genotypes from MAGIC TOM population were not strongly affected by

Table 2. Soluble sugars content ( $100 \mathrm{~g}^{-1}$ dry weight) in tomato fruits exposed to optimal and water deficit conditions

\begin{tabular}{|c|c|c|c|c|c|c|}
\hline \multirow{2}{*}{ Genotype } & \multicolumn{2}{|c|}{ Glucose } & \multicolumn{2}{|c|}{ Fructose } & \multicolumn{2}{|c|}{ Sucrose } \\
\hline & control & drought & control & drought & control & drought \\
\hline Plovdiv & $24.74 \pm 0.21$ & $24.56 \pm 0.33 \mathrm{~ns}$ & $22.15 \pm 0.21$ & $20.95 \pm 0.38 *$ & $1.19 \pm 0.04$ & $2.29 \pm 0.08 * * *$ \\
\hline Levovil & $24.28 \pm 0.56$ & $24.98 \pm 0.18 \mathrm{~ns}$ & $23.53 \pm 0.34$ & $22.32 \pm 0.30^{*}$ & $0.23 \pm 0.02$ & $1.19 \pm 0.04 * * *$ \\
\hline LA1420 & $22.93 \pm 0.16$ & $21.62 \pm 0.47^{* *}$ & $21.15 \pm 0.21$ & $19.25 \pm 0.27 * * *$ & $0.63 \pm 0.03$ & $1.48 \pm 0.10^{* * *}$ \\
\hline LA0147 & $23.53 \pm 0.41$ & $19.65 \pm 0.40 * * *$ & $21.64 \pm 0.32$ & $17.57 \pm 0.19 * * *$ & $0.41 \pm 0.03$ & $1.62 \pm 0.07 * * *$ \\
\hline
\end{tabular}

Explantations under Table 1

the different level of stress in repeated drought. These differences can be explained by the varying degree of stress, to which the plants were exposed. Since large tomato fruits exhibited reduction of fruit fresh weight and fruit diameter under water deficit (Table 1), it could be presumed that the higher accumulation of sucrose in these fruits could contribute to osmotic adjustment necessary for continuing fruit growth in water deficit conditions.
Drought also affected organic acids and increased citric acid in the fruits of all genotypes (Table 3), but the effects were more expressed in the large than in cherry fruit. Results of Sun et al. (2014) showed that the increase of organic acid does not necessarily lower the quality of fruits. Increase of both sugars and organic acids could improve tomato fruit quality under water stress (Nahar et al., 2011).

Table 3. Organic acids content ( $\left(100 \mathrm{~g}^{-1}\right.$ dry weight) in tomato fruits exposed to optimal and water deficit conditions

\begin{tabular}{ccccc}
\hline \multirow{2}{*}{ Genotype } & \multicolumn{2}{c}{ Malic acid } & \multicolumn{2}{c}{ Citric acid } \\
\cline { 2 - 5 } & control & drought & control & drought \\
\hline Plovdiv & $1.86 \pm 0.05$ & $2.20 \pm 0.08^{* * *}$ & $4.16 \pm 0.04$ & $4.60 \pm 0.09^{* * *}$ \\
Levovil & $2.57 \pm 0.08$ & $2.31 \pm 0.09 \mathrm{~ns}$ & $4.05 \pm 0.04$ & $4.81 \pm 0.03^{* * *}$ \\
LA1420 & $0.63 \pm 0.03$ & $0.70 \pm 0.02 \mathrm{~ns}$ & $7.35 \pm 0.08$ & $8.13 \pm 0.09^{* *}$ \\
LA0147 & $2.41 \pm 0.08$ & $2.64 \pm 0.06 \mathrm{~ns}$ & $5.01 \pm 0.09$ & $6.14 \pm 0.12^{* * *}$ \\
\hline
\end{tabular}

Explantations under Table 1

Different secondary metabolites, including carotenoids, are responsible for the nutrient and health values of tomato fruits and also are genotype-specific (Schweiggert et al., 2017). Comparison between cherry and large fruits showed that in both optimal and drought conditions fruits of cherry tomato had a higher total carotenoid content than large fruits, mainly due to higher content of lycopene and phytoene (Tables 4 and 5). In this study, the effect of drought stress was more expressed on $\beta$-carotene accumulation than lycopene that could 
Table 4. Lycopene and $\beta$-carotene content $\left(\mathrm{mg} \mathrm{kg}^{-1}\right.$ fresh weight) in tomato fruits exposed to optimal and water deficit conditions

\begin{tabular}{ccccc}
\hline \multirow{2}{*}{ Genotype } & \multicolumn{2}{c}{ Lycopene } & \multicolumn{2}{c}{$\beta$-carotene } \\
\cline { 2 - 5 } & control & drought & control & drought \\
\hline Plovdiv & $73.54 \pm 2.12$ & $74.65 \pm 2.18 \mathrm{~ns}$ & $2.58 \pm 0.09$ & $3.02 \pm 0.07^{* *}$ \\
Levovil & $55.81 \pm 1.64$ & $52.19 \pm 1.45 \mathrm{~ns}$ & $4.72 \pm 0.04$ & $3.43 \pm 0.07^{* * *}$ \\
LA1420 & $68.03 \pm 2.12$ & $101.95 \pm 1.44^{* * *}$ & $3.64 \pm 0.06$ & $4.39 \pm 0.07^{* * *}$ \\
LA0147 & $40.31 \pm 1.82$ & $40.84 \pm 2.30 \mathrm{~ns}$ & $2.92 \pm 0.01$ & $3.27 \pm 0.07^{* *}$ \\
\hline
\end{tabular}

Explantations under Table 1

Table 5. Phytoene and lutein content ( $\mathrm{mg} \mathrm{kg}^{-1}$ fresh weight) in tomato fruits exposed to optimal and water deficit conditions

\begin{tabular}{|c|c|c|c|c|}
\hline \multirow{2}{*}{ Genotype } & \multicolumn{2}{|c|}{ Phytoene } & \multicolumn{2}{|c|}{ Lutein } \\
\hline & control & drought & control & drought \\
\hline Plovdiv & $11.57 \pm 0.28$ & $14.94 \pm 0.49 * * *$ & $0.74 \pm 0.02$ & $0.97 \pm 0.02 * * *$ \\
\hline Levovil & $3.70 \pm 0.11$ & $4.40 \pm 0.1 * *$ & $0.90 \pm 0.03$ & $1.16 \pm 0.02 * * *$ \\
\hline LA1420 & $8.36 \pm 0.14$ & $14.30 \pm 0.10 * * *$ & $0.70 \pm 0.02$ & $1.04 \pm 0.02 * * *$ \\
\hline LA0147 & $4.24 \pm 0.12$ & $4.68 \pm 0.04^{*}$ & $1.15 \pm 0.03$ & $1.57 \pm 0.04 * * *$ \\
\hline
\end{tabular}

Explantations under Table 1

be indirectly connected to their role in the biosynthesis of plant water-stress related hormones as abscisic acid (Riggi et al., 2008).

Tomatoes are characterized by high fruit antioxidant capacity, and many literature data indicated that this trait is genotype specific (Nour et al., 2013; Klunklin, Savage, 2017). Our study showed that long term moderate drought stress induced the increase of total antioxidant capacity in all analysed genotypes, but this effect was more expressed in cherry than in large tomato fruits (Table 6).
The high antioxidant activity of cherry tomato cultivars was also induced by oxidative stress generated by moderate water deficit (Sánchez-Rodríguez et al., 2010). Among the plant antioxidants, ascorbic acid (vitamin C) is a major antioxidant playing a vital role in protecting against various environmental abiotic stresses (Venkatesh, Park, 2014). In our experiment long term drought stress significantly increased total and reduced ascorbic acid contents in all analysed genotypes, especially in cherry tomatoes (Table 6). This increase could be a result of the oxidative stress-induced formation

Table 6. Antioxidant capacity, total and reduced ascorbic acid content of tomato fruits exposed to optimal and water deficit conditions

\begin{tabular}{|c|c|c|c|c|c|c|}
\hline \multirow[t]{2}{*}{ Genotype } & \multicolumn{2}{|c|}{$\begin{array}{c}\text { Antioxidant capacity } \\
\mu \mathrm{mol} \text { TEAC } 1000 \mathrm{~g}^{-1} \mathrm{FW}\end{array}$} & \multicolumn{2}{|c|}{$\begin{array}{l}\text { Total ascorbic acid } \\
\text { mg } 100 \mathrm{~g}^{-1} \mathrm{FW}\end{array}$} & \multicolumn{2}{|c|}{$\begin{array}{l}\text { Reduced ascorbic acid } \\
\text { mg } 100 \mathrm{~g}^{-1} \mathrm{FW}\end{array}$} \\
\hline & control & drought & control & drought & control & drought \\
\hline Plovdiv & $1582.72 \pm 21.03$ & $2863.63 \pm 84.68 * * *$ & $20.78 \pm 0.47$ & $21.26 \pm 0.76^{* * *}$ & $18.24 \pm 0.21$ & $28.70 \pm 0.40 * * *$ \\
\hline Levovil & $1411.54 \pm 18.17$ & $1866.33 \pm 16.83 * * *$ & $24.88 \pm 0.58$ & $27.91 \pm 0.40 * * *$ & $23.41 \pm 0.59$ & $27.43 \pm 0.52 * * *$ \\
\hline LA 1420 & $1370.00 \pm 12.85$ & $2124.00 \pm 22.91 * * *$ & $22.84 \pm 0.71$ & $32.58 \pm 0.97 * * *$ & $22.62 \pm 0.70$ & $29.65 \pm 0.54 * * *$ \\
\hline LA0147 & $1613.21 \pm 16.79$ & $2546.73 \pm 15.39 * * *$ & $22.68 \pm 0.59$ & $28.07 \pm 0.58 * * *$ & $21.94 \pm 0.56$ & $26.77 \pm 0.96 * * *$ \\
\hline
\end{tabular}

Explantations under Table 1; FW - fresh weight

of reactive oxygen species (ROS), where lycopene and $\beta$-carotene could also contribute to antioxidant defence mechanisms in fruit (Fanciullino et al., 2014). Although we did not measure the activity of enzyme related to ROS-detoxification mechanisms, the increase of the nonenzymatic antioxidant components such as carotenoids and vitamin $\mathrm{C}$ in the fruits indirectly indicated the presence of antioxidant protective mechanism in the investigated tomato plants.

According to Ripoll et al. (2016 a), the comparison of fruit quality parameters on dry and fresh weight basis may explain drought effect on tomato fruits. An increase in a certain compound per dry and fresh weight basis indicates that drought induced both, concentration and metabolic effects, while the significant increase only per fresh weight basis indicates that the drought induced a concentration effect.

Use of such approach for assessment of sugars and organic acid data (Table 7) indirectly showed that hexose sugars and organic acids increased significantly in all genotypes mainly due to the concentration effect, although the tendency of increasing the sucrose content, especially in large fruits indicated both, concentration and metabolic accumulation effects.

Results for lycopene and $\beta$-carotene for most genotypes indirectly indicated that their content was mainly the result of decrease in storage / metabolism and can be compensated for by concentration effect, except for LA1420, where the higher accumulation of lycopene was accompanied by metabolic changes. 
Table 7. Relative differences in metabolite components of tomato fruits expressed on fresh and dry matter basis

\begin{tabular}{|c|c|c|c|c|c|c|c|c|}
\hline & \multicolumn{4}{|c|}{ Fresh matter basis } & \multicolumn{4}{|c|}{ Dry matter basis } \\
\hline & 'Plovdiv' & 'Levovil' & LA 1420 & LA0147 & 'Plovdiv' & 'Levovil' & LA 1420 & LA0147 \\
\hline Glucose & +26.61 & +26.94 & +26.01 & +8.08 & -0.73 & +2.88 & -5.71 & -16.5 \\
\hline Fructose & +20.59 & +17.14 & +21.60 & +5.21 & -5.42 & -5.11 & -9 & -18.78 \\
\hline Sucrose & +146.36 & +527.64 & +216.42 & +418.67 & +92.68 & +408.12 & +137.06 & +298.77 \\
\hline Total sugars & +26.52 & +24.65 & +25.89 & +10.45 & -0.58 & +0.98 & -5.28 & -18.45 \\
\hline Citric acid & +40.90 & +46.48 & +47.74 & +58.92 & +10.73 & +18.72 & +10.55 & +22.59 \\
\hline Malic acid & +50.71 & +11.11 & +47.03 & +41.96 & +17.91 & -9.88 & +10.05 & +9.72 \\
\hline Total acids & +43.93 & +32.76 & +47.68 & +53.41 & +12.96 & +7.70 & +11.60 & +18.03 \\
\hline Phytoene & +29.15 & +18.96 & +71.08 & +10.55 & +1.27 & -3.57 & +28.06 & -14.61 \\
\hline Lutein & +31.12 & +28.21 & +48.36 & +40.72 & +2.77 & +3.90 & +11.08 & +8.71 \\
\hline$\beta$-carotene & +16.87 & -27.39 & +20.7 & +12.16 & -6.83 & -41.06 & -7.76 & -13.54 \\
\hline Lycopene & +1.51 & -6.49 & +49.87 & +0.57 & -20.40 & -24.21 & +12.85 & -22.31 \\
\hline Total carotenoids & +5.82 & -6.11 & +50.72 & +5.87 & -16.98 & -23.87 & +13.50 & -20.42 \\
\hline Total vitamin C & +50.46 & +12.18 & +42.63 & +23.74 & +9.9 & +6.75 & +13.61 & -13.83 \\
\hline Reduced vitamin C & +57.38 & +17.15 & +31.08 & +22.01 & +25.85 & -0.6 & -6.71 & -8.64 \\
\hline
\end{tabular}

Note. Values are relative differences expressed as $\%(\%=($ mean drought-mean control $/$ mean control $) \times 100)$; significant differences $(P<0.05)$ between control and treatments are indicated by bold fonts.

\section{Conclusions}

1. Long term water deficit can influence fruit quality in large tomato fruit genotypes by active metabolic accumulation of sucrose and citric acid, which are also osmotically active compounds.

2. Higher reduction of the fruit growth of cherry tomatoes compared to the large fruited tomatoes can be compensated for by improved fruit nutritional value: higher content of ascorbic acid and carotenoids as well as antioxidant activity.

\section{Acknowledgements}

This study was supported by the EU Commission (FP7 project AREA) and Serbian Ministry of Education, Science and Technological Development (project TR 31005)

Received 17042018 Accepted 18102018

\section{References}

1. Ashraf M., Harris P. J. C. 2013. Photosynthesis under stressful environments: an overview. Photosynthetica, 51 (2): 163-190. https://doi.org/10.1007/s11099-013-0021-6

2. Baldwin E. A., Goodner K., Plotto A. 2008. Interaction of volatiles, sugars, and acids on perception of tomato aroma and flavor descriptors. Journal of Food Science, 73: 294-307. https://doi.org/10.1111/j.1750-3841.2008.00825.x

3. Causse M., Stevens R., Amor B. B., Faurobert M., Munos S 2011. Breeding for fruit quality in tomato. Jenks M. A., Bebeli P. J. (eds). Breeding for fruit quality, p. 279-305. https://doi.org/10.1002/9780470959350.ch13

4. Chaves M. M., Oliveira M. M. 2004. Mechanisms underlying plant resilience to water deficits: prospects for water-saving agriculture. Journal of Experimental Botany, 55: $2365-2384$.

https://doi.org/10.1093/jxb/erh269

5. Chaves M. M., Pereira J. S., Maroco J. 2003. Understanding plant response to drought-from genes to the whole plant. Functional Plant Biology, 30: 239-264. https://doi.org/10.1071/FP02076

6. Chen S., Zhou Z. J., Andersen M. N., Hu T. 2015.Tomato yield and water use efficiency - coupling effects between growth stage specific soil water deficit. Acta Agriculturae Scandinavica, 65: 460-469.
7. Dorais M., Ehret D. L., Papadopoulos A. P. 2008. Tomato (Solanum lycopersicum) health components: from the seed to the consumer. Phytochemistry Reviews, 7: 231-250. https://doi.org/10.1007/s11101-007-9085-x

8. Fanciullino A. L., Bidel L. P. R., Urban L. 2014. Carotenoid responses to environmental stimuli: integrating redox and carbon controls into a fruit model. Plant, Cell and Environment, 37: 273-289. https://doi.org/10.1111/pce.12153

9. Gomez L., Rubio E., Auge M. 2002. A new procedure for extraction and measurement of soluble sugars in ligneous plant. Journal of the Science of Food and Agriculture, 82: 360-369. https://doi.org/10.1002/jsfa.1046

10. Jovanovic Z., Stikic R. 2012. Strategies for improving water productivity and quality of agricultural crops in an era of climate change. Lee T. S. (ed.). Irrigation systems and practices in challenging environments. InTech, p. 77-102. https://doi.org/10.5772/29275

11. Klunklin W., Savage G. 2017. Effect on quality characteristics of tomatoes grown under well-watered and drought stress conditions. Foods, 6: 56 https://doi.org/10.3390/foods6080056

12. Kusçu H., Turhan A., Demir A. O. 2014. The response of processing tomato to deficit irrigation at various phenological stages in a sub-humid environment. Agricultural Water Management, 133: 92-103. https://doi.org/10.1016/j.agwat.2013.11.008

13. Lipiec J., Doussan C., Nosalewicz A., Kondracka K. 2013. Effect of drought and heat stress on plant growth and yield: a review. International Agrophysics, 27: 463-477. https://doi.org/10.2478/intag-2013-0017

14. Miller N. J., Diplock A. T., Rice-Evans C., Davies M. J., Gopinathan V., Milner A. 1993. A novel method for measuring antioxidant capacity and its application to monitoring the antioxidant status in premature neonates. Clinical Science, 84: 407-412. https://doi.org/10.1042/cs0840407

15. Nahar K., Ullah S. M., Islam N. 2011. Osmotic adjustment and quality response of five tomato cultivars (Lycopersicon esculentum Mill.) following water deficit stress under subtropical climate. Asian Journal of Plant Science, 10: $153-157$. https://doi.org/10.3923/ajps.2011.153.157

16. Nour V., Trandafir I., Ionica M. E. 2013. Antioxidant compounds, mineral content and antioxidant activity of several tomato cultivars grown in Southwestern Romania. Notulae Botanicae Horti Agrobotanici Cluj-Napoca, 41 (1): 136-142. https://doi.org/10.15835/nbha4119026 
17. Ranc N. 2010. Molecular polymorphism analysis of fruit-quality related genes in wild and cultivated genetic resources: association genes QTL. Ph.D. thesis, University of Montpellier, France, 261 p. (in French). https:// prodinra.inra.fr $/ \mathrm{ft}$ ? $\mathrm{id}=6 \mathrm{CCA} 82 \mathrm{~A} 0-\mathrm{A} 544-42 \mathrm{CA}-92 \mathrm{ED}$ 33C6A0A1FFF5

18. Riggi E., Patane C., Ruberto G. 2008. Content of carotenoids at different ripening stages in processing tomato in relation to soil water availability. Australian Journal of Agricultural Research, 59: 348-353. https://doi.org/10.1071/AR07215

19. Ripoll J., Urban L., Staudt M., Lopez-Lauri F., Bidel L., Bertin N. 2014. Water shortage and quality of fleshy fruits-making the most of the unavoidable. Journal of Experimental Botany, 65: 4097-4117. https://doi.org/10.1093/jxb/eru197

20. Ripoll J., Urban L., Bertin N. 2016 (a). The potential of the MAGIC TOM parental accessions to explore the genetic variability of tomato acclimation to repeated cycles of water deficit and recovery. Frontiers in Plant Science, 6: 3-15. https://doi.org/10.3389/fpls.2015.01172

21. Ripoll J., Urban L., Brunel B., Bertin N. 2016 (b). Water deficit effects on tomato quality depend on fruit development stage and genotype. Journal of Plant Physiology, 190: 26-35.

https://doi.org/10.1016/j.jplph.2015.10.006

22. Sánchez-Rodríguez E., Rubio-Wilhelmi M. M., Cervilla L. M., Blasco B., Rios J. J., Rosales M. A., Romero L., Ruiz J. M. 2010. Genotypic differences in some physiological parameters symptomatic for oxidative stress under moderate drought in tomato plants. Plant Science, 178 (1): $30-40$

https://doi.org/10.1016/j.plantsci.2009.10.001
23. Schweiggert R. M., Ziegler J. U., Metwali E. M. R., Mohamed F. H., Almaghrabi O. A., Kadasa N. M., Carle R. 2017. Carothenoids in mature green and ripe red fruits of tomato (Solanum lycopersicum L.) grown under different levels of irrigation. Archives of Biological Sciences, 69: 305-314. https://doi.org/10.2298/ABS160308102S

24. Sérino S., Gomez L., Costagliola G., Gautier H. 2009. HPLC assay of tomato carotenoids: validation of a rapid microextraction technique. Journal of Agricultural and Food Chemistry, 57 (19): 8753-8760. https://doi.org/10.1021/j9902113n

25. Stevens R., Buret M., Garchery C., Carretero Y., Causse M. 2006. Technique for rapid, small-scale analysis of vitamin $\mathrm{C}$ levels in fruit and application to a tomato mutant collection. Journal of Agricultural and Food Chemistry, 54: 6159-6165. https://doi.org/10.1021/jf061241e

26. Sun Y., Holm P. E., Liu F. 2014. Alternate partial rootzone drying irrigation improves fruit quality in tomatoes. Horticultural Science, 41: 185-191. https://doi.org/10.17221/259/2013-HORTSCI

27. Venkatesh J., Park S. W. 2014. Role of L-ascorbate in alleviating abiotic stresses in crop plants. Botanical Studies, 55: 38. https://doi.org/10.1186/1999-3110-55-38

28. Zheng J., Huang G., Jia D., Wang J., Mota M., Pereira L. S., Huang Q, Xu X., Liu H. 2013. Responses of drip irrigated tomato (Solanum lycopersicum L.) yield, quality and water productivity to various soil matric potential thresholds in an arid region of Northwest China. Agricultural Water Management, 129: 181-193. https://doi.org/10.1016/j.agwat.2013.08.001

ISSN 1392-3196 / e-ISSN 2335-8947

Zemdirbyste-Agriculture, vol. 106, No. 2 (2019), p. 123-128

DOI $10.13080 /$ z-a.2019.106.016

\title{
Drègmès trūkumo įtaka vyšninių ir didžiavaisių pomidorų vaisių kokybei
}

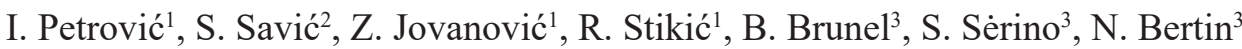 \\ ${ }^{1}$ Belgrado universitetas, Serbija \\ ${ }^{2}$ John Naisbitt universitetas, Serbija \\ ${ }^{3}$ Prancūzijos nacionalinis žemès ūkio tyrimų institutas
}

\section{Santrauka}

Tyrimo metu siekta ištirti ilgalaikio vidutinio sausros streso įtaką keturių tėvinių MAGIC TOM populiacijos formų pomidorų vaisių derliui bei kokybei ir nustatyti vyšninių bei didžiavaisių pomidorų jautrumo sausrai skirtumus. Tyrimo rezultatai parodè, kad ilgalaikis vidutinio sunkumo drègmès trūkumas turèjo neigiamos įtakos žaliai masei bei vaisių skersmeniui, ir tai labiau pasireiškė vyšniniuose nei didžiavaisiuose pomidoruose. Ilgalaikis drègmès trūkumas gali pagerinti didžiavaisių pomidoru vaisių skoni dèl aktyvaus metabolinio tirpiujų cukrų ir organinių rūgščių (sacharozès ir citrinos rūgšties) kaupimosi, kurie taip pat yra osmotiškai aktyvūs junginiai. Lyginant su didžiavaisiais pomidorais, sumažeję̨s vyšninių pomidorų augimas gali būti kompensuojamas gerinant vaisių mitybinę vertę - didinant askorbo rūgšties bei karotenoidų kiekị ir antioksidacinị aktyvumą, dèl medžiagų koncentracijos bei metabolizmo ir spartinant metabolines reakcijas.

Reikšminiai žodžiai: antioksidantų junginiai, MAGIC TOM, mitybinė vertė, sausra, Solanum lycopersicum. 